\title{
Inclusion of Saccharina latissima in conventional anaerobic digestion systems
}

F. Ometto, A. Berg, Annika Björn, Luka Safaric, Bo H. Svensson, A. Karlsson and Jörgen Ejlertsson

The self-archived postprint version of this journal article is available at Linköping University Institutional Repository (DiVA):

http:// urn.kb.se/ resolve?urn=urn:nbn:se:liu:diva-146067

N.B.: When citing this work, cite the original publication.

This is an electronic version of an article published in:

Ometto, F., Berg, A., Björn, A., Safaric, L., Svensson, Bo H., Karlsson, A., Ejlertsson, J., (2018),

Inclusion of Saccharina latissima in conventional anaerobic digestion systems, Environmental technology, 39(5), 628-639. https:// doi.org/ 10.1080/09593330.2017.1309075

Original publication available at:

https:// doi.org/ 10.1080/09593330.2017.1309075

Copyright: Taylor \& Francis (STM, Behavioural Science and Public Health Titles)

http:// www.tandf.co.uk/journals/default.asp 


\title{
Inclusion of Saccharina latissima in conventional anaerobic
}

\section{digestion systems}

\author{
F. Ometto ${ }^{1, *}$, A. Berg${ }^{1}$, A. Björn ${ }^{2}$, L. Safaric ${ }^{2}$, B.H. Svensson ${ }^{2}$, A. Karlsson ${ }^{1}$ and J. \\ Ejlertsson $^{1,2}$
}

${ }^{1}$ Scandinavian Biogas Fuels AB, Research and Development Dept., Stockholm, Sweden; ${ }^{2}$ Linköping University, Dept. of Thematic Studies - Environmental Changes, Linköping, Sweden;

*Corresponding author: francesco.ometto@scandinavianbiogas.com

\section{ABSTRACT}

Loading macroalgae into existing anaerobic digestion (AD) plants allows us to overcome challenges such as low digestion efficiencies, trace elements limitation, excessive salinity levels and accumulation of volatile fatty acids (VFAs), observed while digesting algae as a single substrate. In this work, the co-digestion of the brown macroalgae Saccharina latissima with mixed municipal wastewater sludge (WWS) was investigated in mesophilic and thermophilic conditions. The hydraulic retention time (HRT) and the organic loading rate (OLR) were fixed at 19 days and $2.1 \mathrm{~g} \mathrm{l}^{-1} \mathrm{~d}^{-1}$ of volatile solids (VS), respectively. Initially, WWS was digested alone. Subsequently, a percentage of the total OLR $(20 \%, 50 \%$ and finally $80 \%)$ was replaced by S. latissima biomass. Optimal digestion conditions were observed at medium-low algae loading ( $\leq 50 \%$ of total OLR)

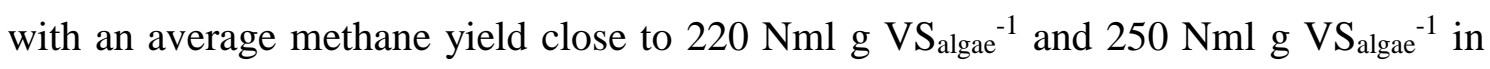
mesophilic and thermophilic conditions respectively. The conductivity values increased with the algae loading without inhibiting the digestion process. The viscosities of the reactor sludges revealed decreasing values with reduced WWS loading at both temperatures, enhancing mixing properties. 


\section{Highlights}

-Efficient algae digestion was observed at organic loading rates $<1 \mathrm{gVS}^{-1} \cdot \mathrm{d}^{-1}$.

-Thermophilic digestion allowed higher algae loading.

-Conductivity values increased over time (+300\%) without affecting AD efficiency.

-Algae addition reduced digester material viscosity enhancing its mixing properties.

\section{Keywords}

Seaweed, co-digestion, salinity, viscosity, biomethane. 


\section{Introduction}

Macroalgae are a valuable biomass for the production of a number of profitable products including biofuels. Having a potential energy content between 10 and $15 \mathrm{MJ} \mathrm{kg}^{-1}$ of dry matter (DM), a value similar to that of energy crops such as sugarcane $\left(11 \mathrm{MJ} \mathrm{kg} \mathrm{DM}^{-1}\right)$, sunflower and rapeseed (19 $\mathrm{MJ} \mathrm{kg} \mathrm{DM}^{-1}$ ), together with the absence of lignin (nonfermentable component), deems macroalgae a promising substrate for anaerobic digestion (AD) $[1,2]$. The Environment Committee of the European Parliament foresees the possibility of macroalgae-derived biofuels covering at least $1.25 \%$ of the total European energy consumption in the transport sector by 2020 [3]. However, there are still a number of obstacles limiting the exploitation of algae for biofuel production at a commercial scale [4,5]. Focusing on biomethane production via $\mathrm{AD}$, these are related to biomass availability, AD process efficiency and profitability.

While high-value algae derived products fulfil the demand of a small market with a relatively low amount of algae biomass ( 0.2 million tonnes of macroalgae harvested in the EU in 2015 [6]), biofuel production requires significantly higher biomass availability. For macroalgae to satisfy the $1.25 \%$ target of the total European energy consumption for transport, more than 150 million tonnes per year would be required [7]. Therefore, despite the large amount of natural algae forests available, commercial utilisation of this biomass requires sustainable production facilities (e.g. algae farms). Algae farms have huge potential, but have to date suffered severe technical and biological difficulties such as determining optimal cultivation and harvesting techniques, experiencing adverse offshore weather conditions and a growth cycle mostly allowing for one harvest per year $[7,8]$. Once harvested, the algae biomass decays quickly [9]. Therefore, the biomass has to be stored and preserved until it is required, or it has to be processed in a short time [7]. 
Storage of algae biomass is costly and still not applicable to intensive production systems, while processing of extensive biomass quantity in a short time implies high organic loading rates (OLRs) in the $\mathrm{AD}$ unit often resulting in low digestion performances. For example, Laminaria digitata, a brown macroalgae available in large quantities in the natural environment and easy to mass cultivate [10], has a theoretical methane potential close to $500 \mathrm{ml} \mathrm{g}^{-1}$ of volatile solids (VS), but experimental data on semi-continuous digestion give in average half of this amount $[11,12]$. This low yield would, assuming an annual biomass availability of 10,000 ton and a total solids (TS) content of $12 \%$ (75\% VS of TS), give a yearly production of $225000 \mathrm{Nm}^{3} \mathrm{CH}_{4}$ from L. digitata. Applying a selling price at the production facilities equal to $0.75 € \mathrm{Nm}^{-3} \mathrm{CH}_{4}$ [13], this gives a potential revenue of $140 €$ ton $\mathrm{DM}^{-1}$, a value 1.5 times lower than the sole estimated harvesting cost for this algae (equal to $250 €$ ton $\mathrm{DM}^{-1}$ ) [14]. Therefore, a better profitability for production of biogas from macroalgae is needed. This can be achieved by higher biomass yields from algae cultivation and use of optimised AD conditions to obtain efficient degradation rates and high methane yields. In the example with L. digitata, a 90\% anaerobic degradation efficiency (instead of 50\%) would increase the biomethane production by $80 \%$ giving a potential income close to $250 €$ ton $\mathrm{DM}^{-1}$ offsetting the harvesting costs. This higher degradation grade, combined with low cost harvesting and cultivation techniques, will be required for macroalgae to be considered as an economically competitive biomass for $\mathrm{AD}[7,8]$.

Co-digestion of algae with complementary substrates has shown promising results by enhancing the efficiency of the algal digestion. For instance, co-digestion of Saccharina latissima with wheat straw (75:25 algae:straw ratio) at a total OLR of $1.5 \mathrm{~g} \mathrm{VS} \mathrm{l}^{-1} \mathrm{~d}^{-1}$ in batch mode, increased the methane yields by $40 \%$ from $200 \mathrm{ml} \mathrm{g} \mathrm{VS}^{-1}$ to $275 \mathrm{ml} \mathrm{g} \mathrm{VS}^{-1}$ 
[15]. More recently, digestion of a mixture of fresh Ulva lactuca with dairy slurry in a semi-continuous system (25:75 algae:slurry ratio) with a total OLR at $2 \mathrm{~g} \mathrm{VS} \mathrm{l}^{-1} \mathrm{~d}^{-1}$ resulted in an algal methane yield at $95 \%$ of its batch potential value [16]. This suggests that it is beneficial to co-digest algal biomass in existing AD plants to increase digestability and methane yields. The co-digestion might however influence the fluid properties of the AD sludge which might lead to changes in rheological properties (e.g. apparent viscosity, limit viscosity and yield stress) possibly leading to inadequate mixing and heat transfer, breakdown of stirrers, and/or foaming. These kind of problems, which can differ in mesophilic and thermophilic conditions, may lead to deteriorations in the overall process performance and increase in energy consumption [17,18,19].

The aim of the study is to investigate the performance of S. latissima in co-digestion with municipal WWS under different conditions including different algae:sludge VS-ratios $(0: 100,20: 80,50: 50$ and $80: 20)$, at both mesophilic $\left(37^{\circ} \mathrm{C}\right)$ and thermophilic $\left(52^{\circ} \mathrm{C}\right)$ conditions. Tests will be performed in lab-scale semi-continuously stirred tank reactors (CSTRs). This will assess the impact of algal biomass on the reactor sludge viscosity at low $\left(<1 \mathrm{gVS} \mathrm{l}^{-1} \mathrm{~d}^{-1}\right)$ and high $\left(1-1.7 \mathrm{gVS} \mathrm{l}^{-1} \mathrm{~d}^{-1}\right)$ algae loading for the first time.

\section{Material and methods}

\subsection{Substrates}

S. latissima was cultivated by SINTEF in Kristiansund, Norway, and harvested at the end of its growth cycle in June 2014. The algae biomass (ca. $200 \mathrm{~kg}$ wet weight) was homogenised in a blender to a particle size $\leq 1 \mathrm{~cm}^{2}$ and stored at $-20^{\circ} \mathrm{C}$ until utilisation. The TS was $10 \%$ and VS 50\% of TS. WWS (primary sludge mixed with waste activated sludge from a recirculation tank) was collected every two weeks from a local municipal 
wastewater treatment plant (Linköping, Sweden) and stored at $4{ }^{\circ} \mathrm{C}$ until utilisation. The TS concentration varied between $4 \%$ and $6 \%$, while the VS concentration was $78 \%$ of TS.

\subsection{Semi-continuous AD reactors}

Four 51 semi-CSTRs, with a working volume of 4 1, were operated in duplicate for 295 days; two in mesophilic $\left(37^{\circ} \mathrm{C}\right)$ and two in thermophilic $\left(52^{\circ} \mathrm{C}\right)$ conditions. The reactors were inoculated with active anaerobic biomass (4 1 to each reactor) from a full scale mesophilic AD plant treating municipal WWS in Linköping (Sweden), and a thermophilic plant treating municipal food waste in Borås (Sweden), respectively. The OLR and HRT were $2.1 \mathrm{gVS}^{-1} \mathrm{~d}^{-1}$ and 19 days, respectively. For the first three HRTs, the reactors were fed with WWS. Subsequently, 20\% (Phase 1 - 20:80 algae:sludge VS-ratio), 50\% (Phase $2-50: 50$ algae:sludge VS-ratio) and 80\% (Phase 3-50:50 algae:sludge VS-ratio) of the WWS was replaced (on VS-bases) by S. latissima biomass, with a minimum interval of three HRTs between the shifts. Mixing was provided at 350-400 rpm for 15 min every 3 $\mathrm{h}$ to reproduce mixing condition for commercial scale $\mathrm{AD}$ plants operated by Scandinavian Biogas Fuels AB (Stockholm, Sweden). Biogas production was measured continuously by Ritter MCG meters (Bochum, Germany). Gas composition measurements $\left(\mathrm{CH}_{4}, \mathrm{CO}_{2}, \mathrm{O}_{2}\right.$ and $\left.\mathrm{H}_{2} \mathrm{~S}\right)$ were undertaken using a Geotech Biogas analyser (Royal Leamington Spa, United Kingdom) once a week on a $24 \mathrm{~h}$ collected sample. Measurements were verified using a standard gas mixture $\left(\mathrm{CH}_{4}\right.$ and $\left.\mathrm{N}_{2}\right)$. All gas yields are given at standard pressure and temperature $\left(0^{\circ} \mathrm{C} ; 100 \mathrm{kPa}\right)$ and as a mean average value of the duplicate. Statistical analysis (ANOVA) of biogas production was carried out as per http://www.r-project.org/, with significance accepted at $\mathrm{p} \leq 0.05$.

\subsection{Batch digestion}


The biomethane potential (BMP) of the substrates was determined after 60 days of mesophilic batch digestion and performed in triplicate, following the procedure reported by Ekstrand et al. [20]. Briefly, a $320 \mathrm{ml}$ glass bottle was filled with $20 \mathrm{ml}$ of fresh inoculum, obtained from the local mesophilic AD plant (Linköping, Sweden), substrate (8 $\mathrm{g}$ for $S$. latissima and $15 \mathrm{~g}$ for the WWS, giving an substrate:inoculum ratio close to 2:1 of VS), $2 \mathrm{ml}$ of saline solution $\left(450 \mathrm{mM} \mathrm{NH}_{4} \mathrm{Cl}, 410 \mathrm{mM} \mathrm{NaCl}, 60 \mathrm{mM} \mathrm{CaCl} 2 \cdot 2 \mathrm{H}_{2} \mathrm{O}\right.$, $\left.29 \mathrm{mM} \mathrm{MgCl}_{2} \cdot 6 \mathrm{H}_{2} \mathrm{O}\right), 0.3 \mathrm{ml} \mathrm{Na} 2 \mathrm{~S}(100 \mathrm{mM}$ solution) and water to reach $100 \mathrm{ml}$ final volume. Biogas production was measured at regular intervals (day 1, 2, 5, 10, 20, 30, 45 and 60) using a Testo 312-3 pressure gauge (Testo AG, Germany). Methane content was determined by GC-FID following the procedure reported by Karlsson et al. [21]. All gas yields are given as average value of a triplicate \pm SD at standard pressure and temperature $\left(0^{\circ} \mathrm{C} ; 100 \mathrm{kPa}\right)$.

\subsection{Analytical procedures}

The VFAs content was determined from $1 \mathrm{ml}$ of liquid samples centrifuged at 12,000 rpm for 10 min. The supernatant was then injected on a GC-FID, following the method reported in Jonsson and Borén [22]. The detection limit was $0.2 \mathrm{mM}$ and the quantification limit was 0.6 mM. An EcoSense® EC300 (Yellow Springs, USA) was used for conductivity measurements. TS, VS, ammonium concentration and $\mathrm{pH}$ were measured in duplicate according to the APHA [23] standard methods. Substrate elemental composition analysis was completed in accordance with the SS 028150-2/ICP-AES method and performed by Eurofins Environment Sweden AB (Lidköping, Sweden). Sugar content and composition analysis were performed by SINTEF (Kristiansund, Norway) according to the APHA [23] standard methods.

Samples for viscosity characterisation were withdrawn at the end of each experimental 
phase (1-3) and analysed immediately or stored at $4{ }^{\circ} \mathrm{C}$ prior to analyses for a maximum of $24 \mathrm{~h}$. Limit and apparent viscosity were measured at shear rates of 800 and $300 \mathrm{~s}^{-1}$, respectively, in triplicate following the three-step protocol described by Björn et al. [18]. A rotational rheometer (RheolabQC SN80609650) equipped with a CC27-SN19237 measuring system and a C-LTD 80/QC cell, coupled with Rheoplus software was used for the analyses. The temperature was fixed at $37^{\circ} \mathrm{C}$ and $52^{\circ} \mathrm{C}$ for the meso- and thermophilic samples respectively. The certified viscosity reference standard Cannon ${ }^{2}$ RT1000 was used for quality control. 


\section{Results and discussion}

\subsection{Substrate characterisation}

Cultivated S. latissima had an average TS content of $10 \%$. Visual observation of the algae identified the presence of fouling biomass (small shellfish and marine microorganisms) as a result of the late harvesting. No fouling was observed on the non-cultivated $S$. latissima. The fouling resulted in an increased ash content (50\% of TS), related to higher contents of elements including iron, copper, magnesium, manganese and titanium in comparison with the same algae specie harvested from the non-cultivated wild biomass (Table 1).

The main inorganic components of the algae biomass was sodium $\left(75 \mathrm{~g} \mathrm{~kg} \mathrm{TS}^{-1}\right)$ and potassium (55 $\left.\mathrm{g} \mathrm{kg} \mathrm{TS}^{-1}\right)$ followed by sulphur, magnesium, calcium, iron and phosphorus (ranging 3.3 to $19 \mathrm{~g} \mathrm{~kg} \mathrm{TS}^{-1}$; Table 1). The sum of arsenic, cadmium, chromium, lead and mercury constituted $0.03 \mathrm{~g} \mathrm{~kg} \mathrm{TS}^{-1}$. The concentrations of trace elements essential for $\mathrm{AD}$, such as cobalt, molybdenum, nickel, selenium, were low in relation to the requirements presented by Montingelli et al. [24]. For the WWS, iron was the main inorganic compound (33 $\left.\mathrm{g} \mathrm{kg} \mathrm{TS}^{-1}\right)$ followed by phosphorus (19 $\left.\mathrm{g} \mathrm{kg} \mathrm{TS}^{-1}\right)$, calcium (15 $\left.\mathrm{g} \mathrm{kg} \mathrm{TS}^{-1}\right)$ and aluminium $\left(12 \mathrm{~g} \mathrm{kgTS}^{-1}\right)$. The concentration of cobalt was similar to that of the algae while molybdenum and nickel levels were two times higher, and selenium four times lower, while the other heavy metals contents were below $0.02 \mathrm{~g} \mathrm{~kg} \mathrm{TS}^{-1}$ (Table 1).

The BMP of the cultivated algae biomass was $240 \pm 5 \mathrm{ml} \mathrm{g} \mathrm{VS}^{-1}$, which is similar to the value of $220 \pm 61 \mathrm{Nml} \mathrm{g} \mathrm{VS}^{-1}$ reported by Vivekanand et al. [15] for S. latissima biomass cultured in the same area and environment. However, higher values, $340 \pm 36 \mathrm{Nml} \mathrm{g} \mathrm{VS}^{-1}$, were reported for processing the same algae, non-cultivated and harvested from a 
different location [12]. In addition, the processed algae biomass was characterised by a low sugar content. Compared with expected values exceeding $10 \%$ of the dry weight, the measured laminarin and mannitol content was equal to $0.2 \%$ and $3.8 \%$, respectively [cf. $9,25]$. The low sugar content partly explains the low BMP value obtained in the study, confirming the impact of cultivation location and conditions, and harvesting time, on the overall biomass composition [26].

Compared with the algae biomass, the WWS showed a significantly higher $(+48 \%)$ methane potential equal to $360 \pm 9 \mathrm{Nml} \mathrm{g} \mathrm{VS}^{-1}$. Therefore, while replacing an increasing amount of the OLR with algae biomass, a decrease in the potential methane production occurred. An increasing proportion of VS with a high methane yield (360 Nml g VS sludge $^{-}$

${ }^{1}$ ) was replaced with VS with a low methane yield (240 Nml g $\left.\mathrm{VS}_{\mathrm{algae}^{-1}}\right)$. When changing the ratio from 100\% WWS (which yielded $360 \mathrm{Nml} \mathrm{g} \mathrm{VS}^{-1}$ ) to 20:80 algae:sludge, 50:50 and 80:20, the estimated BMP value decreased to 350, 300 and $270 \mathrm{Nml} \mathrm{g} \mathrm{VS}^{-1}$, respectively.

\subsection{Digestion performance}

During the first three HRTs municipal WWS was the sole substrate and a biogas production of 470 and $510 \mathrm{Nml} \mathrm{g} \mathrm{VS}^{-1} \mathrm{~d}^{-1}$ was reached at mesophilic and thermophilic conditions, respectively (Figure 1 - Control). With a methane content of $61 \%$ (Table 2) this gave a methane production close to 300 and $350 \mathrm{Nml} \mathrm{g} \mathrm{VS}^{-1} \mathrm{~d}^{-1}$ at mesophilic and thermophilic conditions, respectively. The total solids content in the reactor was $2.7 \%$ (65\% VS of TS) resulting in a VS reduction close to $60 \%$ in both systems (Table 2).

On day 65 , the substitution of $20 \%$ of the OLR with algae biomass caused a drop in the biogas production of about $15 \%$ in accordance with the lower BMP value of the new feeding (Figure 1 - Phase 1, 20\% algae). After 3 HRTs, the total biogas production at 
$37^{\circ} \mathrm{C}$ had stabilised at $450 \mathrm{Nml} \mathrm{g} \mathrm{VS}{ }^{-1} \mathrm{~d}^{-1}$. This value is equal to $280 \mathrm{Nml} \mathrm{CH}_{4} \mathrm{~g} \mathrm{VS}^{-1} \mathrm{~d}^{-}$ ${ }^{1}$ and it covers $80 \%$ of the estimated BMP value for this level of co-digestion resulting in a calculated total VS reduction of 50\%. Assuming that the VS-reduction of the WWS is still $60 \%$, this means that the algal biomass was subjected to $25 \%$ VS reduction. Higher yields and VS reduction were observed at $52^{\circ} \mathrm{C}$, where biogas and methane production were close to 470 and $300(+7 \%) \mathrm{Nml} \mathrm{g} \mathrm{VS}^{-1} \mathrm{~d}^{-1}$, respectively. This corresponds to $52 \%$ total VS reduction and 30\% VS reduction of the algae biomass (60\% VS reduction applied to WWS).

The additional algae biomass loading introduced into the system from day 145 (Figure 1 - Phase 2, 50\% algae) did not impact the average biogas/methane production for the first HRT. However, from day 170 a decrease in production was observed for all reactors followed by an increase during the third HRT (days 198-215). All reactors showed similar methane production; $260 \mathrm{Nml} \mathrm{g} \mathrm{VS}{ }^{-1} \mathrm{~d}^{-1}$, which corresponds to $86 \%$ of the estimated BMP value for this phase. The total VS reduction was stable at $50 \%$ and $52 \%$ for the mesophilic and thermophilic processes, respectively, but a greater percentage of the algal biomass was now digested (48-50\% algal VS-reduction).

During the final phase of the experiment (Figure 1 - Phase 3, 80\% algae) the behaviour of the duplicate reactors at both mesophilic and thermophilic conditions differed significantly $(p<.05$ between all 4 reactors) indicating inefficient AD process. This was confirmed by the shift in the total VFA and pH values between days 215 and 295 (Figure 2). During the instable period the methane yield of the most affected mesophilic reactor dropped to 60-100 $\mathrm{Nml} \mathrm{g} \mathrm{VS}^{-1} \mathrm{~d}^{-1}$, after 2 HRTs. However, from day 265 and onwards $\left(3^{\text {rd }} \mathrm{HRT}\right)$, the reactor increased the production to values between 230 and $250 \mathrm{Nml} \mathrm{CH}_{4}$ $\mathrm{g} \mathrm{VS}^{-1} \mathrm{~d}^{-1}$, equal to $85-95 \%$ of the BMP value. A similar behaviour occurred at 
thermophilic conditions, however, higher methane yields $(+30 \%$ compared to the mesophilic reactors) were maintained (Figure 1 - Phase 3, 80\% algae). Between days 216 and 265 the methane production gradually decreased to $200 \mathrm{Nml} \mathrm{CH}_{4} \mathrm{~g} \mathrm{VS}^{-1} \mathrm{~d}^{-1}$. After day 265 , the methane yield increased to over $250 \mathrm{Nml} \mathrm{CH}_{4} \mathrm{~g} \mathrm{VS}^{-1} \mathrm{~d}^{-1}$ as a result of higher digestion rates with total and algae VS reduction between $50 \%$ and $55 \%$.

Overall, these results confirm that anaerobic co-digestion of S. latissima and WWS is a feasible way forward for the use of algal biomass as a substrate in AD. The estimated methane production from the solemnly algae biomass at $37^{\circ} \mathrm{C}$ during the first phase $(20 \%$ algae) was equal to $200 \mathrm{Nml} \mathrm{g} \mathrm{VS}{ }^{-1}$ representing $83 \%$ of the BMP value of S. latissima. When using a 50:50 algae:sludge ratio condition, the estimated production increased to $220 \mathrm{Nml} \mathrm{gVS}^{-1} \mathrm{~d}^{-1}$ (92\% of the BMP value) suggesting that this combination is close to optimal conditions for co-digestion of these two substrates. The instability observed at levels above $50 \%$ VS algae (50\% of OLR from algae), is in agreement with previous studies. For instance, Jard et al. [27] reported strong inhibition when processing $S$. latissima and Palmaria palmata in mesophilic conditions with an OLR equal or higher than $2.1 \mathrm{~g} \mathrm{VS} \mathrm{l}^{-1} \mathrm{~d}^{-1}$, with more than $50 \%$ methane yield reduction. Similarly, co-digesting efficiency of Ulva lactuca and dairy slurry (OLR of $2 \mathrm{~g} \mathrm{VS}^{-1} \mathrm{~d}^{-1}$ ) decreased from $95 \%$ to $76 \%$ and $18 \%$ when increasing the algae:slurry ratio from $25: 75$ to $50: 50$ and $75: 25$, respectively [16]. This was also confirmed in thermophilic conditions, where moving from an algae loading rate of $3.3 \mathrm{~g} \mathrm{VS} \mathrm{l}^{-1} \mathrm{~d}^{-1}$ to $2.5 \mathrm{~g} \mathrm{VS}^{-1} \mathrm{~d}^{-1}$ in co-digestion with manure, the average methane yield of Ulva sp. decreased from 250 to $150 \mathrm{ml} \mathrm{g} \mathrm{VS}^{-1}$ algae [28]. Process instability caused highly fluctuating biogas yields (between 50 and $200 \mathrm{ml}$ $\mathrm{g} \mathrm{VS}_{\mathrm{algae}^{-1}}{ }^{-1}$ over the 7 HRTs of observation (115 days), which is similar to the reactor behaviours during phase 3 of the current work. Here, the estimated production after 3 
HRTs ranged 180-250 $\mathrm{Nml} \mathrm{g} \mathrm{VS}^{-1} \mathrm{~d}^{-1}$ at both mesophilic and thermophilic conditions with a biodegradability efficiency varying between $80 \%$ and $95 \%$ of the BMP value.

\section{$3.3 \mathrm{pH}$ and VFA accumulation}

The mesophilic reactors operated at a $\mathrm{pH}$ of around 7.5 until day 215 (Figure 1). Subsequently, during the highest algae loading phase (80\% algae), in correspondence to the low methane yields observed previously, VFA accumulation up to $8 \mathrm{~g}^{-1}$ reduced the $\mathrm{pH}$ value below 7.0. The observed reduction of acetic acid after day 265 and the consequent $\mathrm{pH}$ increase confirmed microbial adaptation to the new feedstock composition enhancing digestion performances (Figure 2).

The effect of the 80:20 algea:sludge load was less pronounced in the thermophilic reactors; the $\mathrm{pH}$ value remained at 8.0 and total VFA did not exceed $3 \mathrm{~g} \mathrm{l}^{-1}$. Temperature is known to impact the microbial community and therefore higher diversity occurs at mesophilic versus thermophilic conditions [29], and higher activity take place at thermophilic conditions [30,31]. This partially justifies the lower VFA accumulation, together with the higher methane yields observed at $52^{\circ} \mathrm{C}$ compared to $37^{\circ} \mathrm{C}$. However, the thermophilic digester behaviour suggests a process capable of digesting higher algae loading despite observed decreasing concentrations of trace elements and high $\mathrm{S}$ with increased algae load (additional information in Table A1). To illustrate, the replacement of WWS with algae over time reduced the concentration of $\mathrm{Co}, \mathrm{Ni}$ and Mo measured in the digested sludge with over $50 \%$, while the loading of S into the system increased from $8 \mathrm{~g} \mathrm{~kg} \mathrm{TS}^{-1}$ (sludge only) to $17 \mathrm{~g} \mathrm{~kg} \mathrm{TS}^{-1}$ (80:20 algae:sludge).

\subsection{Hydrogen sulfide}

The initial $\mathrm{H}_{2} \mathrm{~S}$ concentration was below $5 \mathrm{ppm}$ and increased gradually eventually exceeding $1000 \mathrm{ppm}$ at the end of Phase 2 (50:50 algae:sludge) and $10000 \mathrm{ppm}$ during 
Phase 3 (80:20 algae:sludge) (Table 2). This confirms the findings of Venages and Bartlett [32] on $\mathrm{H}_{2} \mathrm{~S}$ formation when digesting seaweed. However, during the first phase of the experiment, the presence of iron in the WWS gave a Fe:S ratio in the mixed substrate close to $3: 1$, enabling precipitation of the formed sulfide to FeS [33]. When the iron loading was reduced (lower ww sludge load), the Fe:S ratio decreased to 2:1and 1:1, after Phase 2 and3, respectively, and $\mathrm{H}_{2} \mathrm{~S}$ formation occurred.

Although similar $\mathrm{H}_{2} \mathrm{~S}$ concentrations were shown not to give process disturbance during $\mathrm{AD}$ of macroalgae [32], the presence of $\mathrm{H}_{2} \mathrm{~S}$ has a major impact on the economy of the biogas upgrading process and downstream utilisation [14]. This is in contrast to previous work [34]. Despite high $\mathrm{H}_{2} \mathrm{~S}$ concentrations, the higher methane yields observed at thermophilic conditions during the first HRT in Phase 3 (Figure $1-80 \%$ algae), show that this process is more suitable for degradation of high loadings of algae biomass than for mesophilic digestion.

\subsection{Ammonium}

The ammonium concentration increased over time in both systems without exceeding 1.7

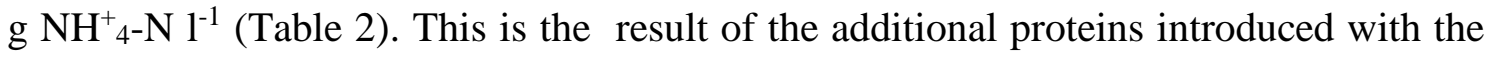
algae (between $3 \%$ and $21 \%$ of the dry matter [2]). Higher values were recorded at thermophilic conditions which is likely to be due to the higher degradation of the nitrogenous organic compounds at $52^{\circ} \mathrm{C}$ than at $37^{\circ} \mathrm{C}$ [cf. 35]. Similar behaviour was observed during co-digesting Ulva sp. (26\% proteins) with mixed WWS in batch mode (15:75 algae:sludge VS-ratio) [16]. Ammonium concentrations of up to $1400 \mathrm{mg} \mathrm{NH}^{+}{ }_{4}^{-}$ $\mathrm{N}^{-1}$ did not affect the AD process [36]. However, when processing protein-enriched algae (50-60\% of dry matter), higher levels of ammonium will occur which may result in the inhibition of the methanogenic population. Nevertheless, the loading of $\mathrm{Na}^{+}, \mathrm{K}^{+}, \mathrm{Ca}^{2+}$ 
and $\mathrm{Mg}^{2+}$, introduced into the system with the algae biomass, will hamper the ammonium inhibition by supporting methanogenic activity [cf. 37,38].

\subsection{Conductivity}

The conductivity value was highly effected by the algae biomass addition (Figure 3 ). Within the reactor, the initial conductivities of the mesophilic and thermophilic conditions were $7.5 \pm 0.1 \mathrm{~ms} \mathrm{~cm}^{-1}$ and $8.7 \pm 0.2 \mathrm{~ms} \mathrm{~cm}^{-1}$, respectively. The conductivity increased linearly with the TS content of algae added by 2, 3 and 5 times for the 20:80, 50:50 and 80:20 algae:sludge VS-ratio, respectively. This reached $37 \mathrm{~ms} \mathrm{~cm}^{-1}$ in both systems after 295 days. In both reactors, stable conductivity values were observed after 2 HRTs after the new feeding composition was started. Constant conditions are a characteristic of efficient and stable AD processes [39]. Therefore, the observed conductivity increment will mainly be due to salt loading $\left(\mathrm{Na}^{+}\right.$and $\left.\mathrm{K}^{+}\right)$, suggesting a stress of the system as a result of the algae addition. In all reactors the concentration of $\mathrm{Na}^{+}$and $\mathrm{K}^{+}$increased over time to reach $0.5 \mathrm{~g}^{-1}$ and $5 \mathrm{~g}^{-1}$ respectively at the end of phase 3 (80:20 algae:sludge). However, these values are below the $6 \mathrm{~g} \mathrm{Na} \mathrm{l}^{-1}$ and $17 \mathrm{~g} \mathrm{~K} \mathrm{l}^{-1}$ identified by Jard et al. [27] to inhibit the methanogenic activity when processing the same alga species $S$. latissima (50\% inhibition).

Although salinity has been proved to inhibit the AD by impacting the methanogens [40], the levels achieved in this work did not seem to affect the methanogenic activity as the methane level in the produced gas remained above $\mathrm{CH}_{4} \geq 60 \%$. (Table 2).

\subsection{Viscosity}

The viscosity values (apparent and limit viscosity) differed between the two digestion systems (Table 2). Higher limit viscosities, between 6.1 and $7.4 \mathrm{mPa}$ s, were measured in mesophilic conditions (thermophilic 4.6 - $5.6 \mathrm{mPa}$ ). In both systems, the increase in TS 
from $3.5 \%$ to $4.5 \%$ between phase 1 (20:80 algae:sludge) and phase 2 (50:50 algae:sludge) did not impact on the limit viscosity values. However, the additional TS increment (>5\%) in Phase 3, due to increased algae loading (80:20 algae:sludge), reduced limit viscosities by $20 \%$. These behaviours confirm that the TS content alone is not a reliable parameter to predict and evaluate changes in viscosity in AD processes. This is as previously reported by the authors in earlier viscosity studies of full-scale biogas reactors with different substrate profiles $[18,41]$. As the structure of digested WWS is governed by steric interactions [42], a high impact on viscosity can be influenced by the presence of extracellular polymeric substances (EPS) in the WWS including filamentous cells, lipids, proteins and biosurfactants [43]. Therefore, together with TS content, the monitoring of these parameters could be an optimal strategy to predict changes in viscosity of the digester fluid and the extent of the mixing demand and associated required energy supply .

\section{Economic feasibility}

Current cultivation practise of S. latissima in Norway would supports an algal biomass production of 100-150 ton (wet weight) ha $\mathrm{ha}^{-1} \mathrm{y}^{-1}[9,44,45]$. For the purpose of this analysis, a 80 ha algae farm has been considered, thus resulting in a production of 10,000 ton $\mathrm{y}^{-1}$. This corresponds to 700-980 ton VS $\mathrm{y}^{-1}$ depending on the biomass' VS content (Table 3). In co-digestion with mixed municipal WWS, this amount of algae could provide between 154000 and $245000 \mathrm{Nm}^{3} \mathrm{CH}_{4}$ depending on the digestion condition applied (Table 3). Hence, with a methane market value of $0.75 € \mathrm{Nm}^{-3}$ [13], 10,000 ton of algae could provide a revenue between 0.12 and 0.19 million Euro when used for biomethane production (Table 3). This value covers only 30-50\% of the estimated price for macroalgae biomass delivered at the $\mathrm{AD}$ site exceeding 0.35 million Euro ( $250 €$ ton $\mathrm{DM}^{-}$ 
${ }^{1}$ as harvesting costs only [14]), confirming the processing of macroalgae for biomethane production non-yet profitable [14].

To turn macroalgae biomass as a profitable biomass for biomethane production, we see three feasible alternatives: (1) algae biomass production costs (cultivation and harvesting) are significantly reduced, or (2) biomethane production from algae is integrated in a biorefinery approach, or (3) innovative strategies to compensate the biomass costs are considered. For (1), based on current costs for the operation of a conventional AD unit treating multiple substrates in Sweden [13], the maximum acceptable selling price for macroalgae delivered at the AD plant premises is estimated to range between 4 and $12 €$ ton $\mathrm{DM}^{-1}$ (Table 3). This value is similar to the one reported by Murthy Konda et al. [8] when considering $S$. latissima for ethanol production $\left(23 €\right.$ ton $\left.\mathrm{DM}^{-1}\right)$. Such low biomass costs can only be achieved with the implementation of low costs harvesting techniques that require new technologies not yet available on the market $[7,24]$.

For (2), the biomass should first be processed for high valuable products (e.g. extraction of proteins and pigments) and the residues then used for biomethane production $[7,8]$. The profit related to the commercialisation of the high-value products will contribute to offset cultivation/harvesting costs supporting commercial competitiveness of algae based biofuels. However, this will impact expected methane yields and the related revenue value as part of the methane potential will be lost in the extracted material (e.g. proteins). For (3), policy makers should consider economically compensated algae farms for the environmental benefits related to macroalgae phytodepuration characteristics $[45,46]$. A macroalgae farm producing 10,000 ton wet biomass has a nutrient uptake equal to 35 ton of nitrogen $[9,47]$. Cultivated in the premises of fish farms, algae have been demonstrated to mitigate nitrogen emissions otherwise untreated [9]. The fixed nitrogen can after 
anaerobic digestion be concentrated using evaporation technic and sold as a liquid fertiliser. To compare, such nitrogen mitigation via conventional European wastewater treatments (waste activated sludge) would cost between 0.4 and 2.7 million Euro [49], enough to offset algae biomass production costs.

\section{Conclusions}

Wastewater sludge is a suitable co-substrate to optimise AD of S. latissima. An algae biomass loading between 0.4 and $1 \mathrm{~g} \mathrm{VS}^{-1} \mathrm{~d}^{-1}$ (OLR algae below $50 \%$ of total OLR) showed a digestion efficiency up to $92 \%$, with average methane yields close to $220 \mathrm{Nml}$ $\mathrm{g} \mathrm{VS}^{-1}$, equal to $15 \mathrm{Nml} \mathrm{g}^{-1}$ of wet biomass. This potentially allows a revenue generation of between 10 and $18 €$ ton $^{-1}$ wet treated biomass, depending on the VS content. The highest algae loading tested $\left(1.7 \mathrm{~g} \mathrm{VS}^{-1} \mathrm{~d}^{-1}\right)$ initially gave an instable digestion process that suffered from VFA accumulation as well as low trace elements concentration. However, both the mesophilic and the thermophilic processes adapted to the high algae load leading to a recovery of VFA concentrations below $2 \mathrm{~g} \mathrm{l}^{-1}$ and re-established methane yields, with the thermophilic process, allowing a faster recovery. The salt loading introduced into the $\mathrm{AD}$ systems with the algae, did not reduce the process efficiency. Furthermore, the highest inclusion of macroalgae reduced the viscosity of the digester material, likely enhancing its mixing properties both at mesophilic and thermophilic conditions. 


\section{Acknowledgments}

The authors would like to thank the European project ATBEST (grant agreement n. 316838), the Swedish Biogas Research Centre (BRC) hosted by Linköping University (Sweden), Biokraft AS (Norway) and SINTEF (Norway) for their financial and intellectual support.

\section{References}

1. Schenk, P.M., Thomas-Hall, S.R., Stephens, E., Marx, U.C., Mussgnug, J.H., Posten, C., Kruse, O., Hankamer, B., 2008. Second generation biofuels: high-efficiency microalgae for biodiesel production. BioEnergy Research 1 (1), 20-43.

2. Rajauria, G., Cornish, L., Ometto, F., Msuya, F.E., Villa, R., 2015. Identification and selection of algae for food, feed and fuel applications. In: Seaweed sustainability: food and non-food applications, Elsevier Ed. ISBN 978-0124186972.

3. European Parliament News, 2015. European Committee backs switchover to advanced biofuels. Press release Environment 24-02-2015. Available at: http://www.europarl.europa.eu/news/en/news-

room/content/20150223IPR24714/html/Environment-Committee-backs-switchoverto-advanced-biofuels.

4. IEA, 2015. Energy and climate change: world energy outlook special report. International Energy Agency. Available https://www.iea.org/publications/freepublications/publication/WEO2015SpecialRep orton EnergyandClimateChange.pdf.

5. Jard, G., Marfaing, H., Carrere, H., Delgenes, J.P., Steyer, J.P., Dumas, C., 2013. French Brittany macroalgae screening: composition and methane potential for 
potential alternative sources of energy and products. Bioresour. Technol. 144, 492498.

6. Rocca, S., Agostini, A., Giuntoli, J., Marelli, L. 2015. Biofuels from algae: technology options, energy balance and GHG emissions: insights from a literature review. EUR 27582; doi 10.2790/125847

7. Murphy, J.D., Drosg, B., Allen, E., Jerney, J., Xia, A., Herrmann, C., 2015. A perspective on algal biogas. IEA Bioenergy ISBN 978-1-910154-18-2.

8. Murthy Konda, N.V.S.N., Seema, S., Simmons, B.A., Klein-Marcuschamer, D. 2015. An investigation on the economic feasibility of macroalgae as a potential feedstock for biorefineries. Bioenerg. Res. 8, 1046-1056.15.

9. Handå A., Forbord, S. Wang, X., Broch, O.J., Dahle S.W., Størseth, T.R. Reitan, K.E., Olsen, Y., Skjermo, J., 2013. Seasonal- and depth-dependent growth of cultivated kelp (Saccharina latissima) in close proximity to salmon (Salmo salar) aquaculture in Norway. Aquaculture 414, 191-201.

10. Milledge, J., Smith, B., Dyer, P., Harvey, P. 2014. Macroalgae-derived biofuel: a review of methods of energy extraction from seaweed biomass. Energies. 7, 71947222.

11. Adams, J.M.M, Toop, T.A., Donnison, I.S., Gallagher, J.A. 2011. Seasonal variation in Laminaria digitata and its impact on biochemical conversion routes to biofuels, Bioresour. Technol. 102, 9976-9984.

12. Allen, E., Wall, D.M., Herrmann, C., Xia, A., Murphy, J.D., 2015. What is the gross energy yield of third generation gaseous biofuel sourced from seaweed? Energy 81, $352-360$. 
13. Ejlertsson, J., 2016. Personal communication based on Scandinavian Biogas Fuels AB anaerobic digestion operation during period 2015, Sweden.

14. Bruton, T., Lyons, H., Lerat, Y., Stanley, M., Rasmussen, M.B. 2009. A review of the potential of marine algae as a source of biofuel in ireland. Sustainable Energy Ireland Dublin. Available at: http://scholar.google.com/scholar?hl=en\&btnG=Search\&q=intitle:A+Review+of+th e+Potential+of+Marine+Algae+as+a+Source+of+Biofuel+in+Ireland\#0.

15. Vivekanand, V., Eijsink, V.G.H., Horn, S.J., 2012. Biogas production from the brown seaweed S. latissima: thermal pre-treatment and co-digestion with wheat straw. J. Appl. Phycol. 24, 1295-1301.

16. Allen, E., Wall, D.M., Herrmann, C., Murphy, J.D., 2014. Investigation of the optimal percentage of green seaweed that may be co-digested with dairy slurry to produce gaseous biofuel. Bioresour. Technol. 170, 436-444.

17. Nordberg, А̊., Ekström, M., 2005. Co-digesting of energy crops and the source-sorted organic fraction of municipal solid waste. Water Sci. Technol. 52 (1-2), 217-222.

18. Björn, A., Segura de La Monja, P., Karlsson, A., Ejlertsson, J., Svensson, B.H., 2012. Rheological characterization. In: Biogas, InTech Ed, ISBN 979-953-307-221-9.

19. Lindmark, J., Thorin, E., Bel Fdhila, R., Dahlquist, E., 2014. Effects of mixing on the result of anaerobic digestion: a review. Renew. Sustain. Energ. Rev. 40, 1030-1047.

20. Ekstrand, E-M., Larsson, M., Truong, X-B., Cardell, L., Borgström, B., Björn, A., Ejlertsson, J., Svensson, B.H., Nilsson, F., Karlsson, A., 2013. Methane potentials of the Swedish pulp and paper industry - a screening of wastewater effluents. Appl. Energ. 112, 507-517. 
21. Karlsson, A., Ejlertsson, J., Nezirevic, D., Svensson, B.H., 1999. Degradation of phenol under meso- and thermophilic, anaerobic conditions. Anaerobe 5 (1), 25-35.

22. Jonsson, S., Borén, H., 2002. Analysis of mono- and digesters of o-phthalic acid by solid phase extractions with polystyrene-divinylbenzene-based polymers. J. Chromatogr. 963, 393-400.

23. APHA, 2011. Standard methods for the examination of water and wastewaters American Public Health Association/American Water Works Association/Water Environment Federation. Washington DC, USA. 2540 B, E. Solids.

24. Montingelli, M.E., Tedesco, S., Olabi, A.G., 2015. Biogas production from algal biomass: a review. Renew. Sustain. Energ. Rev. 43, 961-972.

25. Philippsen, A., Wild, P., Rowe, A., 2014. Energy input, carbon intensity and cost for ethanol produced from farmed seaweed. Renew. Sustain. Energ. Rev. 38, 609-623.

26. Schiener, P., Black, K.D., Stanley, M.S., Green, D.H., 2015, The seasonal variation in the chemical composition of the kelp species L. digitata, L. hyperborea, S. latissima and A. esculenta. J. Appl. Phycol. 27, 363-373.

27. Jard, G., Jackowiak, D., Carrère, H., Delgenes, J.P., Torrijos, M., Steyer, J.P., Dumas, C., 2012. Batch and semi-continuous anaerobic digestion of Palmaria palmata: comparison with Saccharina latissima and inhibition studies. Chem. Eng. J. 209, 513519.

28. Nielsen HB, Heiske S., 2011. Anaerobic digestion of macroalgae: methane potentials, pre-treatment, inhibition and co-digestion. Water Sci. Technol. 64 (8),1723-1729.

29. Levén L., Eriksson A.R.B., Schnürer A., 2007. Effect of process temperature on bacterial and archaeal communities in two methanogenic bioreactors treating organic household waste. FEMS Microbiology Ecology 59 (3), 683-93. 
30. Moonil, K., Ahn, Y.H., Speece, R.E., 2002. Comparative process stability and efficiency of anaerobic digestion; mesophilic vs. thermophilic. Water Res. 36 (17), 4369-4385.

31. Niu, Q., Takemura, Y., Kubota, K., Li, Y.Y., 2015. Comparing mesophilic and thermophilic anaerobic digestion of chicken manure: Microbial community dynamics and process resilience. Waste Manage. 43, 114-22.

32. Vanegas, C.H., Bartlett, J., 2013. Green energy from marine algae: biogas production and composition from the anaerobic digestion of Irish seaweed species. Environ. Technol. 34 (15), 2277-2283.

33. Shakeri Yekta, S., Svensson, B.H., Björn, A., Skyllberg, U., 2014. Thermodynamic modelling of iron and trace metal solubility and specification under sulfidic and ferruginous conditions in full scale continuous stirred tack reactors. Appl. Geochem. 47, 61-73.

34. Cecchi F., Pavan P., Mata-Alvarez J., 1996. Anaerobic co-digestion of sewage sludge: application to the macroalgae from the Venice lagoon. Resour. Conserv. Recy. 17, $57-66$.

35. Song, Y.C., Kwon, S.J., Woo, J.H., 2004. Mesophilic and thermophilic temperature co-phase AD compared with single-stage mesophilic- and thermophilic digestion of sewage sludge. Water Res. 38, 1653-1662.

36. Costa, J.C., Gonçalves, P.R., Nobre, A., Alves, M.M., 2012. Biomethanation potential of macroalgae Ulva spp. and Gracilaria spp. and in co-digestion with waste activated sludge. Bioresour. Technol. 114, 320-326.

37. Kugelman, I.J., McCarty, P.L., 1965. Cation toxicity and stimulation in anaerobic waste treatment. Journal of Water Pollution Control Federation 37 (1), 97-116. 
38. Chen, Y., Cheng, J., Creamer, K., 2008. Inhibition of anaerobic digestion process: a review. Bioresour. Technol. 99, 4044-4064.

39. Blanc, F.C., Molof, A.H., 1973. Electrode potential monitoring and electrolytic control in anaerobic digestion. Journal Water Pollution Control Federation 45 (4), 655-667.

40. Lefebvre, O., Quentin, S., Torrijos, M., Godon, J.J., Delgenès, J.P., Moletta, R., 2007. Impact of increasing $\mathrm{NaCl}$ concentrations on the performance and community composition of two anaerobic reactors. Appl. Microbiol. Biot. 75 (1), 61-69.

41. Šafarič, L., Ejlertsson, J., Shakeri-Yekta, S., Karlsson, A., Ometto, F., Svensson, B.H., Björn, A., 2015. Viscosity characteristics of CSTR biogas processes as affected by substrate composition. Proceeding of IWA World Congress on Anaerobic Digestion, 15-18th Nov., Vina del Mar, Chile.

42. Foster, C.F., 2002. The rheological and physico-chemical characteristics of sewage sludges. Enzyme Microb. Tech. 30, 340-345.

43. Ganidi, N., Tyrell, S., Cartmell, E., 2009. Anaerobic digestion foaming causes - A review. Bioresour. Technol. 100, 5546-5554.

44. Sanderson, J.C., Dring, M.J., Davidson, K., Kelly, M.S., 2012. Culture, yield and bioremediation potential of Palmaria palmata (Linnaeus) Weber \&Mohr and Saccharina latissima (Linnaeus) C.E. Lane, C.Mayes, Druehl \& G.W. Saunders adjacent to fish farm cages in northwest Scotland. Aquaculture 354-355, 128-135.

45. Skjermo, J., Forbord, S., Handå, A., Steinhovden, K., Fische, S.,Kristova, V., Slizyte, R., 2016. Cultivated S. latissima and A. esculenta as feed protein source. Proceeding of: $22^{\text {nd }}$ International Seaweed Symposium, June $19^{\text {th }}-24^{\text {rd }}$, Copenhagen. 
46. Braun, R. 2009. Biogas from energy crop digestion. IEA Task 37 Brochure, International Energy Agency, Paris, France.

47. Bruun, A., Dolmer, P., Bruunshoj Torring, D., Hasler, B. 2016. The circular economy of seaweed as nutrient management instrument for biobased production. Proceeding of: $22^{\text {nd }}$ International Seaweed Symposium, June $19^{\text {th }}-24^{\text {rd }}$, Copenhagen.

48. Jacob, A., Xia, A., Gunning, D., Burnell, G., Murphy J.D., 2016. Seaweed biofuel derived from integrated multi-trophic aquaculture. International Journal of Environmental Science and Development, 7,11, 805-809.

49. Sutton, M.A., Howard, C.M., Erisma, J.W., Billen, G., Bleeker, A., Grennfelt, P., van Grinsven, H., Grizzetti, B., 2011. The European Nitrogen Assessment. Published by Cambridge University Press. http://www.nine-esf.org/sites/nineesf.org/files/ena_doc/ENA_pdfs/ENA_c22.pdf . 


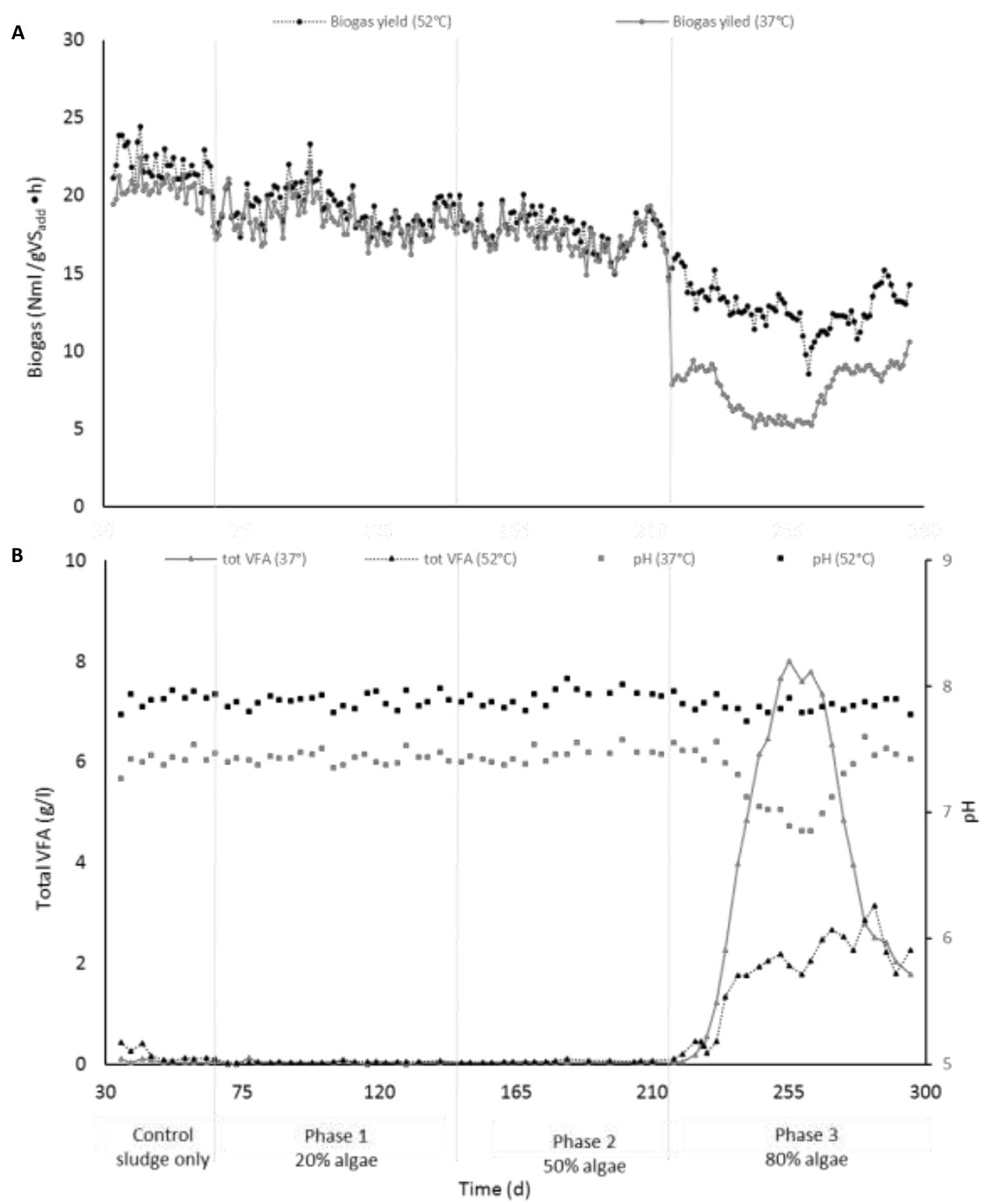

Figure 1 - Reactors' performance under different experimental phases. The algae:sludge VS-ratios changed from 0:100 (Control) to 20:80 (Phase 1), 50:50 (Phase 2) and 80:20 (Phase 3). The OLR was constant at $2.1 \mathrm{gVS} \mathrm{d}^{-1}$. Biogas yields (A), total VFAs (B) and $\mathrm{pH}$ (B) values are reported at mesophilic (grey marks) and thermophilic (black marks) conditions, as an average of duplicate ( $p<.05$ between duplicates). Vertical lines at day 67, 145 and 215 mark the different experimental phases. 


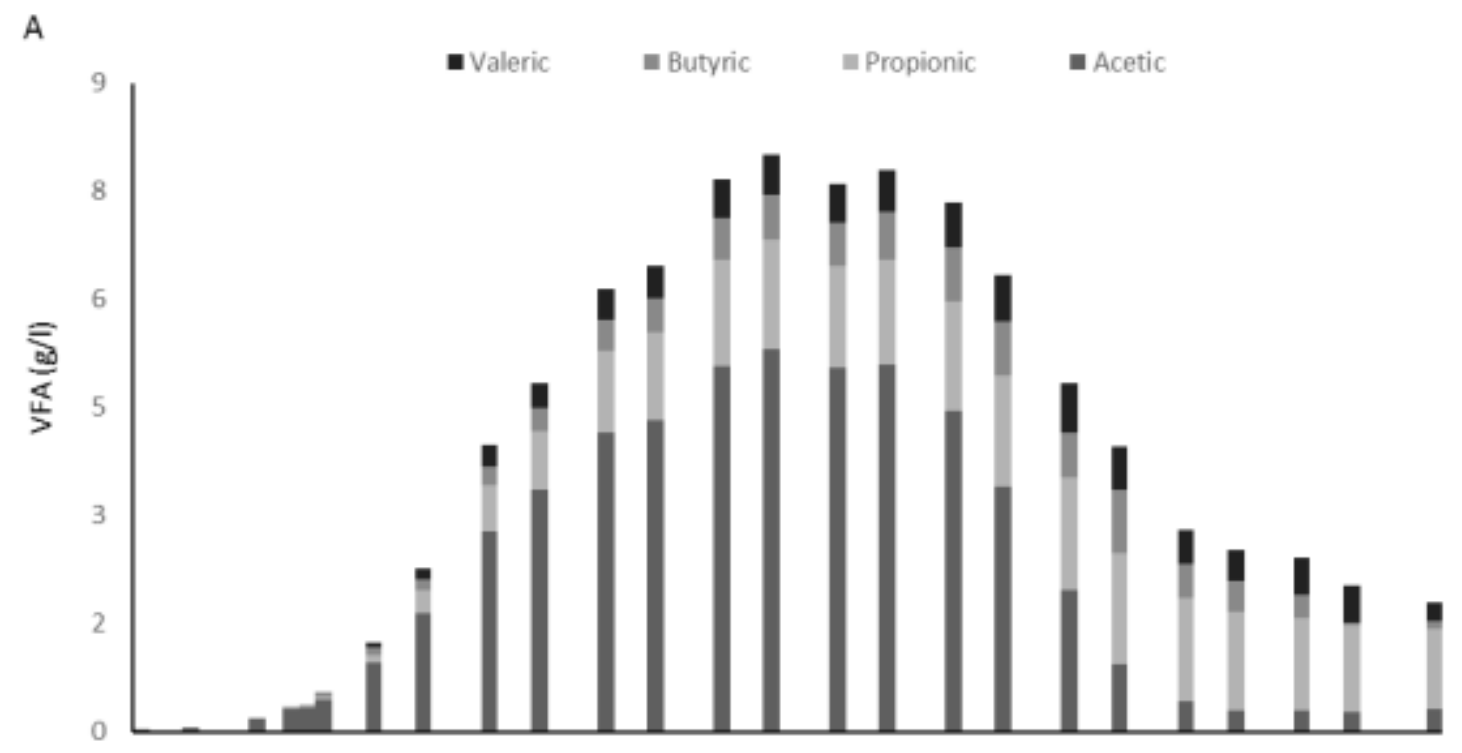

B

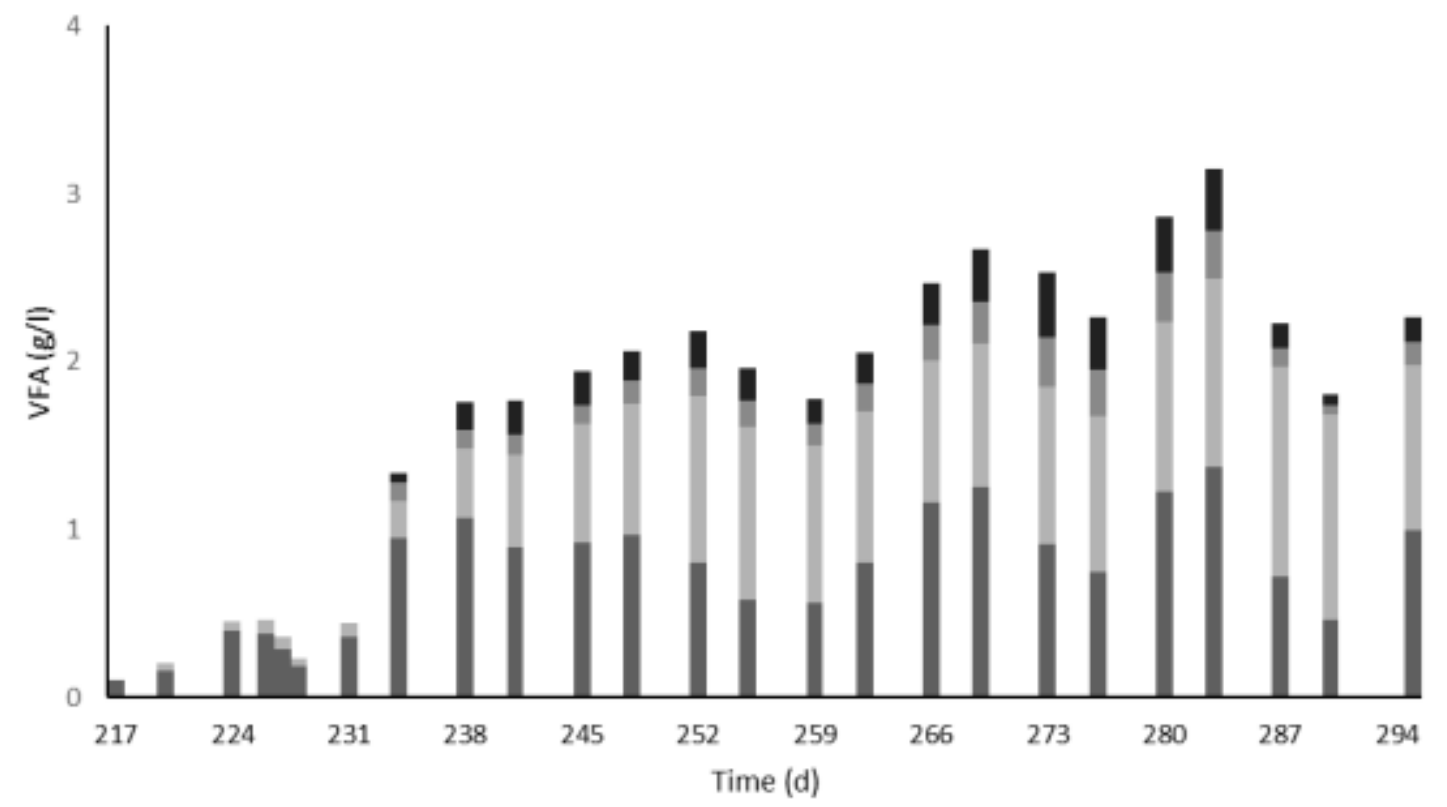

Figure 2 - Specific VFAs composition between days 217 and 295 (80:20 algae:sludge VS-ratio) at mesophilic (A) and thermophilic (B) conditions. Values are reported as average of duplicate samples. 


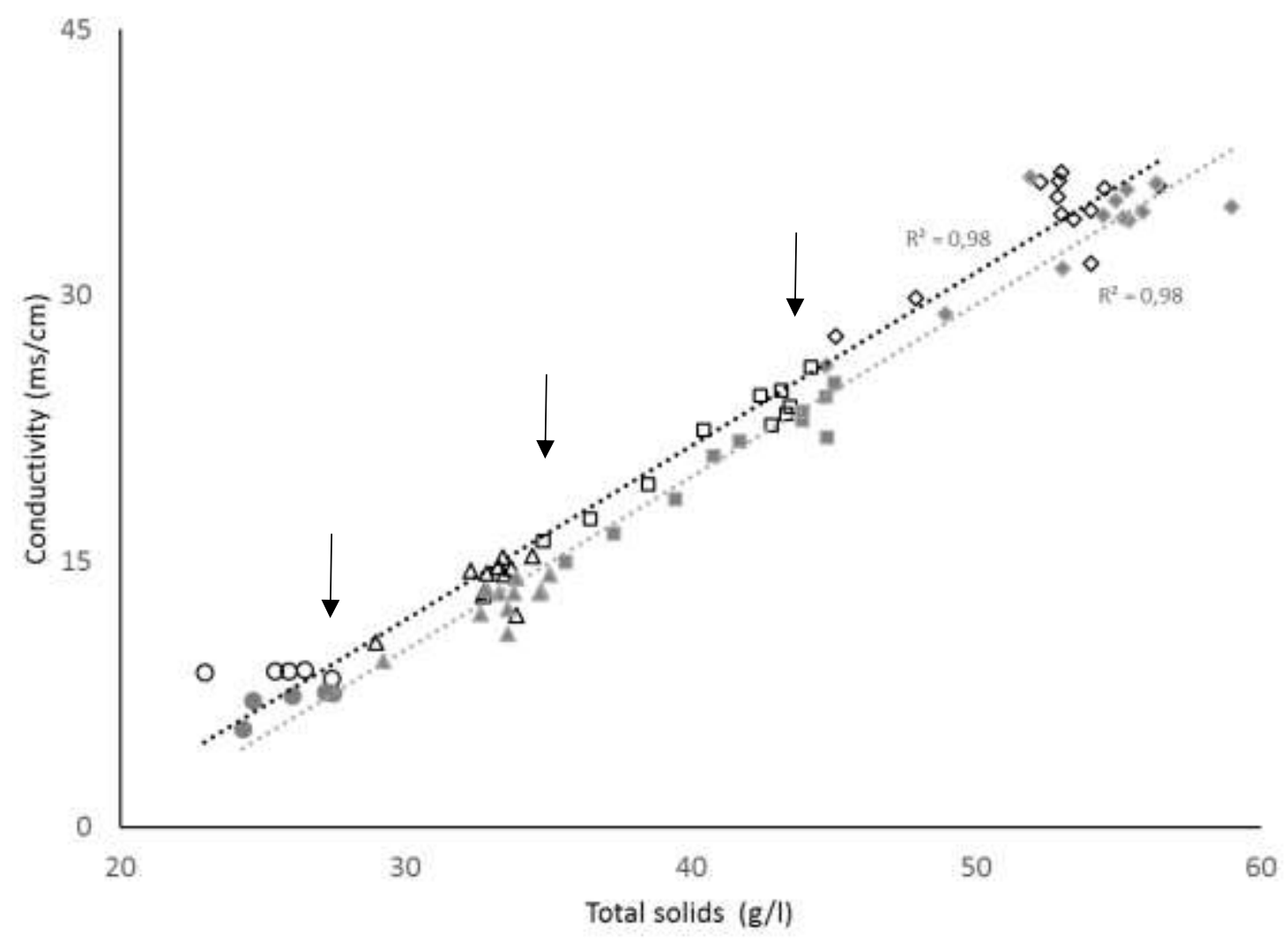

Figure 3 - Conductivity and TS correlation over time at mesophilic (empty markers) and thermophilic (filled markers) conditions. Black arrows mark the end of each experimental phase corresponding to different algae:sludge VS-ratios: circle (0:100), triangle (20:80), square (50:50) and diamond (80:20). Data are presented as an average of duplicate values. 
Table 1 - Elemental composition analysis of processed biomass: comparison between $S$. latissima and wastewater sludge (SS 028150-2/ICP-AES method applied giving 95\% accuracy).

\begin{tabular}{|c|c|c|c|c|}
\hline Element $^{a}$ & $\begin{array}{l}\text { S. latissima cultivated and } \\
\text { harvested in Kristiansund (NO) }\end{array}$ & $\begin{array}{l}\text { S. latissima } \\
\text { harvested in Kristiansund }(\mathrm{NO})^{c}\end{array}$ & $\begin{array}{l}\text { S. latissima } \\
\text { harvested in Clachan Sound (UK) }^{d}\end{array}$ & $\begin{array}{l}\text { Municipal ww sludge } \\
\text { Linköping (SE) }\end{array}$ \\
\hline Al & 130 & 63 & 1877 & 12000 \\
\hline $\mathrm{Sb}$ & $<1$ & $<1$ & - & 1 \\
\hline As & 24 & 68 & 73 & 2 \\
\hline $\mathrm{Ba}$ & 67 & 14 & 22 & 120 \\
\hline $\mathrm{Pb}$ & $<1$ & $<1$ & 2 & 9 \\
\hline B & 140 & 120 & - & 25 \\
\hline $\mathrm{P}$ & 3300 & 2400 & - & 19000 \\
\hline $\mathrm{Fe}$ & 3400 & 230 & 1159 & 33000 \\
\hline $\mathrm{Cd}$ & 2 & 1 & - & $<1$ \\
\hline $\mathrm{Ca}$ & 11000 & 16000 & 18000 & 15000 \\
\hline $\mathrm{K}$ & 55000 & 64000 & 42000 & 2100 \\
\hline Co & $<3$ & $<3$ & - & 3 \\
\hline $\mathrm{Cu}$ & 43 & 3 & 4 & 170 \\
\hline $\mathrm{Cr}$ & 5 & $<3$ & 5 & 8 \\
\hline $\mathrm{Hg}$ & - & - & - & - \\
\hline 1 & - & - & 3193 & - \\
\hline Mg & 12000 & 8200 & 8000 & 1500 \\
\hline $\mathrm{Mn}$ & 23 & 4 & 35 & 130 \\
\hline Mo & 1 & $<1$ & 1 & 4 \\
\hline $\mathrm{Na}$ & 75000 & 48000 & 38000 & 980 \\
\hline $\mathrm{Ni}$ & 6 & $<3$ & 2 & 10 \\
\hline Se & 4 & $<1$ & - & 1 \\
\hline $\mathrm{Ag}$ & $<1$ & $<1$ & - & 1 \\
\hline $\mathrm{Rb}$ & - & - & 33 & - \\
\hline$S$ & 19000 & 11000 & - & 7900 \\
\hline $\mathrm{Sr}$ & - & - & 645 & - \\
\hline $\mathrm{Ti}$ & 12 & $<5$ & 135 & 130 \\
\hline V & $<5$ & $<5$ & - & 7 \\
\hline W & $<1$ & $<1$ & - & 1 \\
\hline $\mathrm{Zn}$ & 85 & 38 & 29 & 360 \\
\hline Dry weight & $14 \%$ & $18 \%$ & $15 \%$ & $6 \%$ \\
\hline Ash content & $50 \%$ & $29 \%$ & $35 \%$ & $22 \%$ \\
\hline
\end{tabular}

${ }^{a}$ data reported in $\mathrm{mg} \mathrm{kgDM}^{-1}$; ${ }^{b}$ biomass cultivated by SINTEF (Norway), harvested in June 2014 and utilised in the present study; ${ }^{c}$ biomass harvested by SINTEF from the wild environment in July 2014 (Norway); ${ }^{d}$ biomass harvested from the wild environment in late May 2011 in the UK (Schiener et al., 2015); "-" means below detectable limit. 
1 Table 2 - Digestate characterisation and biogas composition (mean \pm SD) observed at the end of each experimental phase under different 2 algae:sludge VS-ratios. Limit and apparent viscosity are reported at shear rate of 800 and $300 \mathrm{~s}^{-1}$, respectively.

\begin{tabular}{|c|c|c|c|c|c|c|c|c|c|}
\hline \multirow[b]{2}{*}{ Parameter } & \multirow[b]{2}{*}{ Unit } & \multicolumn{4}{|c|}{$37^{\circ} \mathrm{C}$} & \multicolumn{4}{|c|}{$52^{\circ} \mathrm{C}$} \\
\hline & & Control & $\begin{array}{l}20: 80 \\
\text { algae:sludge }\end{array}$ & $\begin{array}{l}50: 50 \\
\text { algae:sludge }\end{array}$ & $\begin{array}{l}80: 20 \\
\text { algae:sludge }\end{array}$ & Control & $\begin{array}{l}20: 80 \\
\text { algae:sludge }\end{array}$ & $\begin{array}{l}50: 50 \\
\text { algae:sludge }\end{array}$ & $\begin{array}{l}80: 20 \\
\text { algae:sludge }\end{array}$ \\
\hline \multicolumn{10}{|l|}{ Digestate } \\
\hline $\mathrm{pH}$ & & $7.4 \pm 0.1$ & $7.4 \pm 0.1$ & $7.5 \pm 0.1$ & $7.4 \pm 0.1$ & $7.9 \pm 0.1$ & $7.9 \pm 0.1$ & $8.0 \pm 0.1$ & $7.8 \pm 0.1$ \\
\hline TS & $\%$ & $2.7 \pm 0.1$ & $3.5 \pm 0.1$ & $4.5 \pm 0.1$ & $5.5 \pm 0.2$ & $2.6 \pm 0.1$ & $3.4 \pm 0.1$ & $4.4 \pm 0.1$ & $5.3 \pm 0.3$ \\
\hline VS & $\%$ of TS & $65 \pm 1$ & $58 \pm 1$ & $44 \pm 1$ & $34 \pm 1$ & $64 \pm 1$ & $57 \pm 1$ & $44 \pm 1$ & $34 \pm 1$ \\
\hline Ammonia & $\mathrm{mgNH} 4+-\mathrm{N} / \mathrm{l}$ & $1100 \pm 51$ & $1200 \pm 20$ & $1400 \pm 46$ & $1600 \pm 20$ & $1500 \pm 52$ & $1500 \pm 25$ & $1700 \pm 44$ & $1690 \pm 127$ \\
\hline Conductivity & $\mathrm{ms} / \mathrm{mc}$ & $7.6 \pm 0.1$ & $13.7 \pm 0.5$ & $24.2 \pm 0.7$ & $35 \pm 0.5$ & $8.7 \pm 0.2$ & $15.1 \pm 0.4$ & $24.8 \pm 1$ & $37 \pm 0.5$ \\
\hline Limit viscosity & & - & $7.2 \pm 0.6$ & $7.4 \pm 0.3$ & $6.1 \pm 0.5$ & - & $5.3 \pm 0.4$ & $5.6 \pm 0.3$ & $4.6 \pm 0.2$ \\
\hline \multicolumn{2}{|c|}{ Apparent viscoisty $\mathrm{mPa} \cdot \mathrm{s}$} & - & $10 \pm 2$ & $10 \pm 2$ & $7.2 \pm 1.4$ & - & $6.6 \pm 0.3$ & $6.0 \pm 0.9$ & $3.0 \pm 0.3$ \\
\hline Shear stress & $\mathrm{mPa} \cdot \mathrm{s}$ & - & $2.2 \pm 1.8$ & $1.8 \pm 1.2$ & $1.1 \pm 0.5$ & - & $0.8 \pm 0.3$ & $0.7 \pm 0.2$ & $0.3 \pm 0.1$ \\
\hline Biogas & $\mathrm{Pa}$ & & & & & & & & \\
\hline Total yiled & $\mathrm{ml} / \mathrm{gVS} \cdot \mathrm{d}$ & $470 \pm 23$ & $440 \pm 5$ & $410 \pm 12$ & $230 \pm 24$ & $520 \pm 15$ & $460 \pm 16$ & $430 \pm 11$ & $310 \pm 21$ \\
\hline $\mathrm{CH}_{4}$ & $\%$ & $65 \pm 1$ & $64 \pm 1$ & $61 \pm 2$ & $59 \pm 3$ & $65 \pm 1$ & $64 \pm 1$ & $62 \pm 1$ & $61 \pm 4$ \\
\hline $\mathrm{CO}_{2}$ & $\%$ & $35 \pm 1$ & $36 \pm 1$ & $40 \pm 2$ & $41 \pm 1$ & $35 \pm 1$ & $35 \pm 1$ & $39 \pm 2$ & $39 \pm 2$ \\
\hline $\mathrm{H}_{2} \mathrm{~S}$ & ppm & - & - & $1100 \pm 296$ & $>10000$ & $<5$ & $<2$ & $1100 \pm 278$ & $9350 \pm 100$ \\
\hline
\end{tabular}


Table 3 - Economic assessment for the AD of 10,000 ton of S. latissima in co-digestion with mixed municipal wastewater sludge at 9 mesophilic and thermophilic condition.

\begin{tabular}{|c|c|c|c|c|c|c|c|}
\hline \multirow{2}{*}{ Parameters } & \multirow{2}{*}{ Unit } & \multicolumn{6}{|c|}{ Degestion condition } \\
\hline & & \multicolumn{3}{|c|}{ Mesophilic $\left(37^{\circ} \mathrm{C}\right)$} & \multicolumn{3}{|c|}{ Thermophilic $\left(52^{\circ} \mathrm{C}\right)$} \\
\hline S. latissima VS content ${ }^{\mathrm{a}}$ & $\%$ of TS & 50 & 60 & 70 & 50 & 60 & 70 \\
\hline Biomass $^{b}$ & tonVS/y & 700 & 840 & 980 & 700 & 840 & 980 \\
\hline Processing time $^{c}$ & days & 43 & 53 & 61 & 43 & 53 & 61 \\
\hline Methane $^{d}$ & $\mathrm{~m}^{3} \mathrm{CH}_{4} / \mathrm{y}$ & 154000 & 185000 & 216000 & 175000 & 210000 & 245000 \\
\hline Revenue $^{\mathrm{e}}$ & $\begin{array}{l}\text { million } € / y \\
€ / \text { ton wet biomass }\end{array}$ & $\begin{array}{l}0.12 \\
12\end{array}$ & $\begin{array}{l}0.15 \\
15\end{array}$ & $\begin{array}{l}0.16 \\
16\end{array}$ & $\begin{array}{l}0.14 \\
14\end{array}$ & $\begin{array}{l}0.16 \\
16\end{array}$ & $\begin{array}{l}0.19 \\
19\end{array}$ \\
\hline Maximum biomass costs ${ }^{\dagger}$ & $€ /$ ton DM & $4-7$ & $5-9$ & $6-10$ & $4-8$ & $6-10$ & $6-12$ \\
\hline \multicolumn{8}{|c|}{ adata based on observed VS variation for S. latissima as reported in Table 1 (current work). } \\
\hline \multicolumn{8}{|c|}{ bconsidering an annual biomass availability of 10,000 ton wet biomass (14\%TS) [45]. } \\
\hline \multicolumn{8}{|c|}{${ }^{\mathrm{c}}$ considering an existing AD plant (two reactors of $8000 \mathrm{~m}^{3}$ ) with enough spare capacity to accept an algae biomass loading equals to $1 \mathrm{~g}$ VS } \\
\hline \multicolumn{8}{|c|}{$\begin{array}{l}\text { econsidering a selling price for methane equals to } 0.75 € \mathrm{Nm}^{-3} \text { (mean value based on the Swedish market } 2016 \text { where the price for methane } \\
\text { purchased at the AD site varies between } 0.65 \text { and } 0.85 € \mathrm{Nm}^{-3}[13] \text { ). }\end{array}$} \\
\hline \multicolumn{8}{|c|}{ f considering maximum biomass costs to secure a margin of profitability equal to $40-55 \%$ of the revenue from sold methane at the AD site } \\
\hline [13]. & & & & & & & \\
\hline
\end{tabular}


20 Table A1 - Digestate characterisation observed at the end of each experimental phase

21 under different algae:sludge VS-ratios, under mesophilic and thermophilic conditions.

22 Data are presented as an average of duplicate reactors (SS 028150-2/ICP-AES method

23 applied giving $95 \%$ accuracy).

\begin{tabular}{|c|c|c|c|c|c|c|c|c|}
\hline \multirow[b]{2}{*}{ Element $^{a}$} & \multicolumn{4}{|l|}{$37^{\circ} \mathrm{C}$} & \multicolumn{4}{|l|}{$52^{\circ} \mathrm{C}$} \\
\hline & Control & $\begin{array}{l}20: 80 \\
\text { algae:sludge }\end{array}$ & $\begin{array}{l}50: 50 \\
\text { algae:sludge }\end{array}$ & $\begin{array}{l}80: 20 \\
\text { algae:sludge }\end{array}$ & Control & $\begin{array}{l}20: 80 \\
\text { algae:sludge }\end{array}$ & $\begin{array}{l}50: 50 \\
\text { algae:sludge }\end{array}$ & $\begin{array}{l}80: 20 \\
\text { algae:sludge }\end{array}$ \\
\hline $\mathrm{Al}$ & 9600 & 9575 & 5650 & 3300 & 9050 & 9525 & 5700 & 3500 \\
\hline $\mathrm{Sb}$ & 1 & 1 & 1 & 1 & 1 & 1 & 1 & 1 \\
\hline As & 4 & 11 & 20 & 25 & 4.58 & 12.5 & 20 & 25 \\
\hline $\mathrm{Ba}$ & 247 & 135 & 125 & 54 & 208 & 133 & 104 & 57 \\
\hline $\mathrm{Pb}$ & 17 & 18 & 8 & 4 & 17 & 18 & 9 & 4 \\
\hline B & 25 & 52 & 105 & 115 & 25 & 40 & 100 & 115 \\
\hline$P$ & 31250 & 23500 & 16000 & 9900 & 32500 & 23750 & 16000 & 10000 \\
\hline $\mathrm{Fe}$ & 65750 & 38500 & 26250 & 11000 & 56250 & 37000 & 25750 & 11500 \\
\hline $\mathrm{Cd}$ & 1 & 1 & 1 & 2 & 1 & 1 & 1 & 2 \\
\hline $\mathrm{Ca}$ & 30500 & 47500 & 79000 & 90000 & 44500 & 48750 & 75250 & 86500 \\
\hline K & 5575 & 21500 & 46250 & 58000 & 12800 & 23000 & 46750 & 63000 \\
\hline Co & 4 & 3 & 2 & 2 & 3 & 3 & 2 & 2 \\
\hline $\mathrm{Cu}$ & 320 & 203 & 130 & 60.5 & 270 & 202.5 & 150 & 65 \\
\hline $\mathrm{Cr}$ & 40 & 25 & 14 & 9 & 17 & 13 & 20 & 16 \\
\hline Mg & 3125 & 6000 & 11000 & 12000 & 3425 & 6100 & 10750 & 12000 \\
\hline $\mathrm{Mn}$ & 238 & 150 & 98 & 51 & 225 & 148 & 97 & 53 \\
\hline Mo & 10 & 7 & 4 & 3 & 8 & 6 & 6 & 4 \\
\hline $\mathrm{Na}$ & 3375 & 27500 & 61250 & 75000 & 9975 & 29750 & 61250 & 80500 \\
\hline $\mathrm{Ni}$ & 34 & 20 & 12 & 7 & 18 & 14 & 16 & 11 \\
\hline Se & 2 & 2 & 4 & 5 & 2 & 3 & 4 & 4 \\
\hline $\mathrm{Ag}$ & 2 & 2 & 1 & 1 & 1 & 2 & 1 & 1 \\
\hline$S$ & 11975 & 15250 & 19500 & 15500 & 11250 & 15750 & 18500 & 14000 \\
\hline $\mathrm{Ti}$ & 308 & 110 & 73 & 38 & 248 & 105 & 69 & 38 \\
\hline V & 12 & 8 & 6 & 5 & 10 & 7 & 6 & 5 \\
\hline W & 2 & 1 & 1 & 1 & 2 & 1 & 1 & 1 \\
\hline $\mathrm{Zn}$ & 583 & 430 & 298 & 170 & 530 & 428 & 303 & 175 \\
\hline $\mathrm{TS}^{b}$ & 3 & 4 & 5 & 5 & 2 & 3 & 4 & 5 \\
\hline VS of TS ${ }^{b}$ & 66 & 58 & 45 & 38 & 64 & 57 & 44 & 37 \\
\hline Chloride $^{b}$ & 2 & 6 & 12 & 16 & 2 & 6 & 12 & 17 \\
\hline Total Kjeldahl nitrogen ${ }^{b}$ & 8 & 7 & 6 & 5 & 9 & 7 & 6 & 6 \\
\hline Ammonium nitrogen ${ }^{b}$ & 4 & 3 & 3 & 2 & 5 & 4 & 4 & 3 \\
\hline
\end{tabular}

$25{ }^{a}$ data reported in $\mathrm{mg} \mathrm{kgDM}^{-1}$; ${ }^{b}$ data reported as a percentage of dry mass. 